\title{
研究グループ 紹介
}

\section{青山学院大学 理工学部電気電子工学科 生体計測 - 感性工学研究室}

\author{
野澤 昭雄（青山学院大学）
}

\section{1. はじめに}

現代社会において，生体計測の応用は医療・福祉分野に 留まらない。未曾有の少子化と高齢化が同時進行し，健康 長寿と生産性の両立が社会的課題となっている我が国で は，生活習慣病の予防とストレスの管理は重要なテーマで あり，これに資する日常的な生体計測の需要が高まってい る。また，自動運転技術や生産現場の省人化が進み，人と 機械の関わり方が大きく変容していく中で，ユーザーの安 全を確保するための生体計測技術も益々重要になってい る。このように生体計測技術は今後，情報通信機器，自動 車，家庭，オフィス，工場などへの導入を通じて，社会生 活全般において重要な役割を担うことが期待されている。

生体計測の方法は生理的応答の種類や特性に応じて，主 に電気磁気的計測，光学的計測，熱的計測が用いられてき た。従来，医療・福祉の臨床においては，多数の電極・セ ンサを身体に装着する電気磁気的生体計測が主流であった が，日常生活一般への応用に向けて，近年は身体動作を制 約しない生体計測技術の開発が進められている。

本稿では，非侵襲かつ無拘束な生体計測手法の一つとし て注目されている多波長顔画像による生体情報の計測・評 価技術を中心に，我々の研究グループの取り組みを紹介す る。

\section{2. 主な研究内容}

〈2·1〉多波長顔画像計測による遠隔血圧推定日常的 な血圧モ二タリングは，高血圧症に起因する心臓・脳血管 疾患の早期発見や予防において重要である。被計測者がス トレスを感じず無意識的にかつ可及的速やかに血圧を計測 できるよう，力フを用いない低拘束な計測方法が求められ ている。近年，脈波伝搬速度，脈波伝搬時間，加速度脈波 などに基づくカフレス血圧計測技術が提案されている。 我々の研究グループでは，遠隔より撮影した顔面の可視／ 近赤外／熱画像の空間特徵量と血行動態の関連性に基づく 遠隔血圧推定技術について研究している。本手法は，血行 動態の力学モデルである Windkessel モデルに類推を得て， 顔面の血行動態を，空間的に分布する様々な抵抗を持つ血 管系と様々な容量の熱容量によって構成される静的な回路 系によって表現したことに着想を得ている。さらに本手法 の応用に向けて，取得した顔画像に対して独立成分分析や 深層二ューラル・ネットワークを用いることにより，多波 長顔画像の空間的特徵量のみを用いた血圧の推定モデルを 得ることに挑戦している。

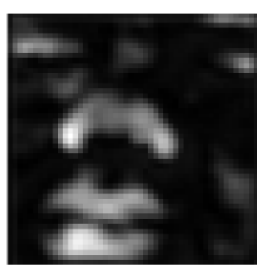

(a) High level

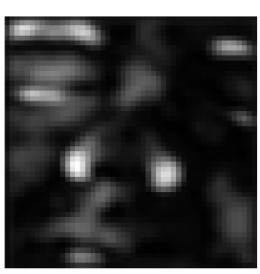

(b) Middle level

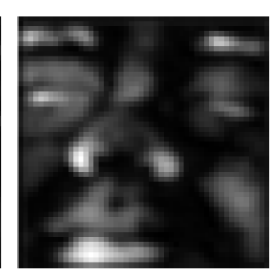

(c) Low level
図 1 顔面熱画像の深層学習に基づく血圧段階推定

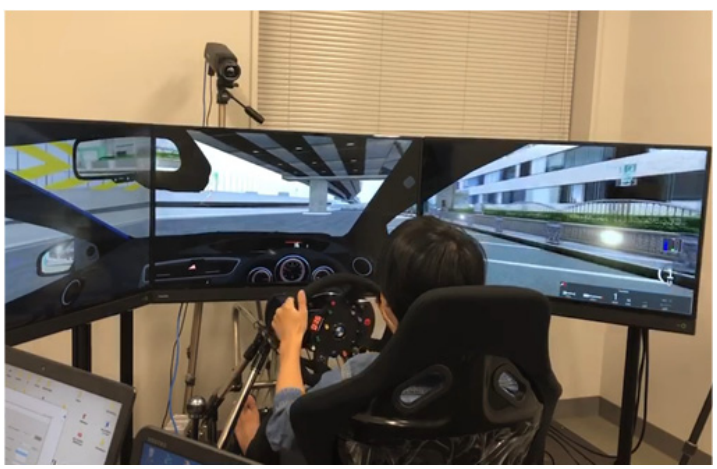

図 2 運転シミュレータを用いた生体計測実験の様子

〈2・2〉遠隔生体計測を応用した感性応答計測 「感覚か ら心理までの情報処理プロセス」を「感性」の一定義とす ると，感性とは個人そのものである。感性応答の計測と評 価は感性工学の基幹領域の一つであり，人間の心と身体の 状態を客観的かつ定量的に捉える事を目指して，心理学， 生理学，情報科学，工学にまたがる学際的な研究がなされ ている。我々の研究グループでは，前述の遠隔生体計測技 術を応用した自律神経系活動推定手法を用いて，「ストレ ス」「嗜好」「集中」「眠気」等の感性応答の計測手法を探求 している。例えば，製品に対する評価構造分析や製品の使 用感評価に感性応答計測手法を応用すべく，製造業界企業 との共同研究も多数実施している。また，自動運転の時代 に向けた自動車乗員モニタリング技術への応用も検討して いる。

\section{3. おわりに}

本稿では，当方にて実施している主な研究について紹介 した。これまで長年に亘り本学会には，生体計測とその工 学的応用研究に関する論文発表の機会を賜ると共に，様々 な学問領域の諸先生方と巡り合う場を提供して頂いた事に ついて，この場をお借りして感謝申し上げます。

(令和 3 年 5 月 20 日受付) 